Tanja Golić

\title{
RELIGIJA IZMEĐU TEORIJE I PRAKSE ${ }^{1}$
}

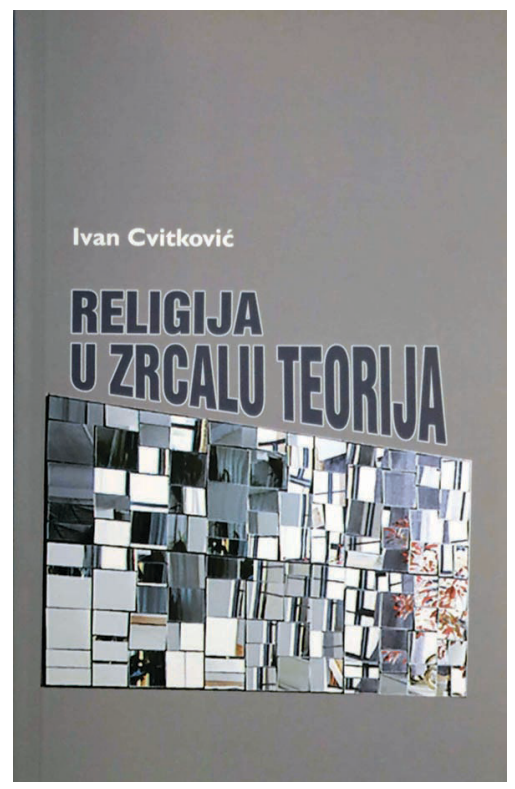

Prof. dr Ivan Cvitković u svom delu Religija $u$ zrcalu teorija pokazuje da pojam religije nije nešto fiksno čija se suština može izraziti samo jednom definicijom. Pojam religije je teško definisati posebno u savremenom društvu. Nisu jasne razlike i granice između postojeće duhovnosti i sekularizacije, tradicionalnosti i fundamentalizma, religijske slobode i religijskog nacionalizma, tradicionalnosti i alternativa... Autor pravi razliku između verovanja i religije. Verovanje je nešto što pripada individui u njenom odnošenju prema svetu i onome što ona smatra da je $u$ njegovoj osnovi. To je stvar njenog unutrašnjeg uverenja. Religija je objektivirano verovanje koje ima svoju društvenu realnost $u$ određenoj religijskoj praksi (str. 12). Zadatak sociologa religije jeste da se bavi samom religijskom praksom, tj. onim što pojedinci čine "u ime svetih spisa". Autor se stoga ne bavi tumačenjem izvornih religijskih tekstova i pitanjem njihovog smisla i značenja, niti se bavi različitim pojedinačnim uverenjima. On pre svega ispituje različite religijske prakse koje su osnova za formiranje teorija o samoj religiji.

Pod pojmom religije se najčešće misli na tri svetske religije (budizam, hrišćanstvo i islam) ili na neke od nacionalnih religija (hinduizam, judaizam, konfučijanstvo, šintoizam, sikizam...) Ipak, religiju kao jedinstven pojam, koji bi predstavljao jedinstvo svih različitih praksi, nije moguće izraziti jednom definicijom. Ono što je zajedničko religijama jeste da sve one imaju neke svoje specifične obrede, heroje i datume. Međutim, sociologija religije je izrazito evropocentrična i u svojim tumačenjima može da zapadne u "uči-

\footnotetext{
${ }^{1}$ Prikaz knjige Religija u zrcalu teorija. Religija\&tolerancija, Novi Sad, br. 25/2016, str. 163-172.
} 
tavanje" azijskim i afričkim religijama nešto iz evropskog diskursa što njima ne pripada (str. 11). Sam autor je zbog toga u svom tumačenju veoma oprezan i kroz predstavljanje različitih teorija se drži unutrašnje terminologije same religije o kojoj govori, kao i niza različitih primera koji pripadaju diskursu same religije o kojoj govori.

Autor se bavi pre svega različitim teorijama u sociologiji religije koje su nastale od XIX veka do danas. Svi značajniji sociolozi XIX veka (Max Veber, Emile Durkheim, Georg Simmel...) su se bavili i pitanjem religije i njenog nastanka i odnosa prema društvu, institucijama, politici, naciji, državi... Sociolozi XX veka su nastavili sa istraživanjem religije u ovom pravcu. Sociologija religije XXI veka se ne bavi više pitanjem nastanka same religije, već se pretežno bavi komparacijama među religijama. Danas je akcenat na pitanjima dijaloga među religijama, tolerancije, pluralizma mišljenja, multikulturalizma itd. Veliki teoretičari u sociologiji religije su Nemci i Francuzi (str. 14). Nemci (Marx, Veber) su se prevashodno bavili istraživanjem različitih teorija religije, a Francuzi (Durkheim, La Bras) empirijskom sociologijom religije. U današnjem vremenu dolazi do napuštanja velikih teorija u sociologiji religije i sociolozi se sve više okreću kvantitativnom pristupu koji podrazumeva statistička merenja, računanja, analiziranja i sistematizovanja različitih empirijskih podataka do kojih dolaze svojim istraživanjima. Ipak, sam autor naglašava da pravo sociološko istraživanje religije mora da ide između empirije i teorije, kako bi bilo potpuno (str. 18).

Za sociologa religije ne postoji nešto što je istinita ili lažna religija. Sociologija religije nije sluškinja neke pojedinačne religije (iako su se dešavali pokušaji da se opšti pojam religije podvede pod neke posebne kategorije). Ne postoji istinita ili lažna religija, već samo njena pojava u društvenoj realnosti. "Naime, ne postoji identitet, pa ni religijski, koji ne uključuje odnos prema drugom." (str. 16) Zbog toga teorije koje autor prikazuje u svom delu nemaju jednu jedinstvenu tezu koja ih povezuje. Knjiga je podeljena na onoliko delova koliko teorija autor izlaže. To su: funkcionalističke i neofunkcionalističke teorije, marksističke i neomarksističke teorije, teorije sukoba, postmodernističke teorije, sekularizacijske teorije, feminističke teorije, teorija globalizacije, ekološke teorije, fundamentalističke teorije, humanizam, teorija identiteta, pravne teorije, ostale teorije (altruistička, antropološka, kreacionistička, konstruktivistička, teorija racionalnog izbora, strukturalistička teorija, tehnologija i religija, verske zabrinutosti).

Autor ne nameće svoje lična uverenja, niti određen teorijski okvir iz koga treba pristupiti različitosti ovih teorija. On je na samom početku pokazao da ne postoji tako nešto što bi bilo jedinstvena definicija religije, već kroz niz 
različitih ključnih teorija u sociologiji religije ostavlja čitaocu da proceni šta je to što je ključno. Stoga je uloga interpretatora veoma bitna za ovo delo, jer on sam iz niza socijalnih teorija i pregršti primera iz najrazličitijih religijskih praksi treba da razluči ne šta je ono što religija jeste, već kako se ona ispoljava kroz različite prakse. Sâm naslov dela Religija u zrcalu teorija upućuje na to da se ono kako religija jeste ogleda preko teorija koje su pokušale da je odrede. Posao tih teorija nije ni danas gotov. On je beskrajan onoliko koliko postoji beskrajnih polja mogućnosti da se prikažu same religijske prakse. Stoga, ako bismo mogli da makar ocrtamo autorovu poziciju, ona bi bila negde između različitih religijskih teorija i prakse, celine i pluralizma mišljenja. Autorovo mišljenje nije savremena bespozicionalnost, ali ne nudi ni gotovu teoriju. To čini ovo delo veoma zanimljivim za čitaoca. Ono je napisano za stručnu publiku, ali njega može čitati i neko ko nije obrazovan isključivo u polju sociologije religije. Svakom čitaocu je jednako upućen poziv da razume različitosti religijskih praksi i teorija i da proširi ne samo formalno obrazovanje nego i sopstvene vidike u okviru religije, ma kakvo da je njegovo lično opredeljenje. Stoga, cilj ovog dela nije da dâ čitaocu gotove odgovore, već da ga proširujući njegovo saznanje navede da postavi sebi pitanje da li je danas, kad smo svesni razlika i sličnosti koje postoje među religijskim praksama, bolje opredeliti se i biti dogmatičan i kritički nastrojen ili je ipak rešenje u otvorenosti i pokušaju razumevanja drugog? Autor u tom smislu daje savremen odgovor pokazujući da mi ne moramo da se odreknemo svojih uverenja i teorija da bismo razumeli drugog, da je važan dijalog sa drugim koji će nam pomoći da proširimo sopstvena stanovišta. Različitost teorija i autora koje izlaže i na koje se poziva najbolje pokazuju njegovu spremnost da uvaži najrazličitija mišljenja.

Njegov stil pisanja je jednostavan, ali bogat sadržajem i informacijama koje potiču iz najrazličitijih kultura. Posebnu pažnju privlače citati koji stoje iznad pojedinih poglavlja koji referišu na suštinu teme o kojoj govori. Tako se čitalac motiviše i upućuje putem gnomske mudrosti u sam sadržaj teksta na jedan inspirativan način.

Autor, kada govori of funkcionalističkim i neofunkcionalističkim teorijama, izlaganje započinje kineskom poslovicom: "Svako na svoj način tumači nebesku glazbu" (str. 39), a izlaganje nastavlja vraćajući se evropskim misliocima (gde su glavni osnivači ovih teorija A. Comte, H. Spencer, E. Durkheim, B. Malinowski, T. Parsons), ne bi li pokazao da različite kulture i načini mišljenja ipak imaju neke sličnosti i da je dijalog i između najrazličitijih načina mišljenja moguć. Naime, funkcionalističke teorije pokazuju kakvu religija ulogu ima u društvu i počele su sa razvojem još u XIX veku. Autor pokazuje 
uspone i padove ove teorije, što je korisno za samog čitaoca - da vidi i njene pozitivne i negativne posledice. Naime, funkcionalistička teorija se zasniva na pozitivističkom mišljenju i prosvetiteljskoj veri u progres. Njen osnivač je A. Comte, koji veruje da je prvi stadijum čovečanstva religijski i da njega prevladava znanost u modernom i savremenom svetu. Međutim, poznato je da posle svetskih ratova ovaj način mišljenja zapada u krizu, stoga se i sama teorija nalazi u krizi. Postoji mnoštvo autora i u filozofiji, poput Edmunda Husserla, koji u svom čuvenom delu Kriza evropskih nauka ukazuje na negativne posledice prosvetiteljskog načina mišljenja. Međutim, funkcionalistička teorija nalazi izlaz u religiji, jer pokazuje da nije važno pitanje kako je religija nastala, ni da li je ona istinita, nego pitanje kakvu ulogu ona igra u društvu i kako njena uloga može biti pozitivna. Ona pozitivnu ulogu religije vidi u njenoj mogućnosti da sprovede mir i dijalog među ljudima. Njena funkcija je pre svega integrativna i u svojim pozitivnim posledicama teži da se razvija. Ono što je korisno jeste što autor pokazuje sličnosti i razlike između različitih predstavnika ove teorije. Tako pokazuje kako je H. Spencer povezao funkcionalizam i evolucionizam u religiji, dok je E. Durkheim stavio akcenat religije na njenu praksu i obrede, pokazujući da ona može imati i dezintegrativnu funkciju. T. Parson će staviti akcenat upravo na dezintegrativu funkciju, a B. Malinowski pokazuje da je religija samo uteha za pojedinca, a ne sredstvo kohezije u društvenoj praksi. Autor navodi i niz drugih različitih imena, pokazuje da integrativnu ulogu mogu da igraju i drugi oblici mišljenja i verovanja, ne samo religija. On daje primere i u konkretnim religijama i istorijskim događajima, kako je dolazilo do raskola i pomirenja, što je korisno za čitaoca - da vidi različite mogućnosti mišljenja. Funkcija religije može biti i psihološka, i u poboljšanju komunikacije, ali autor ne propušta da naglasi ni odnos religije i ekonomije. On postavlja pitanje odnosa gospodara i roba u religijskim zajednicama, pozivajući se i na život jednog mesije, Isusa, ali i na druge proroke i načine života, kao i na različite teorije iz sociologije religije i pitanje uređenja tržišnog sistema i kapitalističkog društva. Čitaocu se ostavlja da do nekih zaključaka dođe sâm. Neofunkcionalizam, kao i funkcionalizam, odlikuje pre svega potreba da se pokaže odnos religije i društva i ne bavi se pitanjem (ne)postojanja Boga.

Sličan pristup autor ima i analizirajući druge teorije. Tako on baveći se marksističkim teorijama u okviru religije razbija predrasude da marksističko učenje nužno ukida religijski način mišljenja. Glavni predstavnici ove teorije su K. Marks i F. Engels. Autor insistira na razlici između Marksovog učenja i marksizma - njegovih loših interpretacija. Religija je za njega nadgradnja nad materijalnom bazom, specifična vrsta duhovne proizvodnje. Ateizam je 
po njemu poslednja faza i stupanj u religijskom razvoju, gde na mesto religije stupa saznanje. Ali to ne znači nužno da nju nasilno treba ukinuti, kako neki tumače Marksa. Po njemu, ona je negativna samo ukoliko opravdava postojeći sistem u kome je čovek otuđen, ali, kako autor nalaže uzimajući Weberovo učenje za primer, ona može imati i pozitivnu funkciju u oslobađanju. "Marx nije kritizirao religiju uopće, već 'otuđenu', ideologiziranu i ispolitiziranu religiju njegovog doba” (str. 72). Autor upućuje na kritičke teorije koje su se nadovezale na Marksa, pre svega na Frankfurtsku školu, tako da čitalac ima uvid u širu sliku marksističkog učenja i sâm može da proceni vrednosti ovih teorija.

Na trećem mestu autor analizira različite teorije sukoba, koje nasuprot integrativnoj funkciji pokazuju kako religija može biti i izvor sukoba i kako je u svojoj istoriji to uglavnom i bila. Autorov pristup je za neiskusnog čitaoca naizgled preopterećen sadržajem, jer on nabraja niz imena koji su na neki način sudelovali u kreiranju ove teorije. To su: B. Russel, K. Malik, E. Roterdamski, S. Sremac, U. Eco, B. Pascal, D. Ćosić itd. Ipak, pažljivom čitaocu neće promaći da autor to čini da bi pokazao važnost ove teorije i način na koji je ona percipirana sa mnogo različitih strana. Tako on analizira i momente nasilja koji postoje ili ne postoje u samim svetim spisima ili životima proroka, kao i odnose između žrtava, koji su doneli sa jedne strane religijsko mišljenje, a sa druge ateizam (poređenje Staljina i verskih sukoba). Autor nudi takođe različite statističke podatke o uverenjima građana o verskim sukobima. On daje primere najviše sa tla evropskog i islamskog sveta, ali i judaizma, jer je evropsko tlo što se tiče verskih sukoba ipak među vodećim u istoriji. Korisno je za čitaoca što autor daje dva prikaza religijskih sukoba: jedan je opšteistorijski, a drugi povesni prikaz, koji uključuje precizne godine, događanja i posledice verskih sukoba. Ono što je važno naglasiti jest da sociologa religije manje interesuje sâm verski sukob, dok se više posvećuje pitanju onoga što je u pozadini tog sukoba, a to su uglavnom materijalni interesi i ponekad ideološka ubeđenja. Iako autor nudi pluralizam mišljenja kada govori o najrazličitijim teorijama, on izričito naglašava da je svaki govor o nasilju kao mogućem rešenju apsurdan. "Naravno, svako nasilje je apsurdno, a religijsko nasilje i nasilje u ime religije još apsurdnije" (str. 99). Tako autor pokazuje da je njegova pozicija donekle savremena i da pre svega poziva na dijalog kao osnovni oblik komunikacije, pokazujući čitaocu da religijska ubeđenja i sukobi među njima ne mogu da budu rešenja. On daje primere i iz savremenih dešavanja, govori i o dešavanjima na Balkanu, pokazujući mogućnost da religija bude osnovni izvor sukoba. Marksističke teorije bi nastojale pokazati da iza svakog sukoba stoji neki ekonomski razlog, a ipak ne govore sve teorije o 
tome. Neke ostavljaju prostora i različitim subjektivnim uverenjima i ideologijama da budu presudne u sâmom sukobu. Autor zaključuje poglavlje mišlju da svako može imati svoja uverenja dok ne ugrožava drugog i da primat svačijeg razmišljanja treba da bude na mirnom ostvarenju interesa.

Važno poglavlje predstavlja i poglavlje o postmodernističkim teorijama. Autor ne ulazi previše u pojedinačne teorije, nego fino, na opšti način, pokazuje kako je došlo do krize modernog načina mišljenja i "prelaska" u postmodernu. Osnovna karakteristika modernog načina mišljenja je poverenje u saznajnu stranu čovekove prirode. Kao što je u srednjem veku religija bila glavna u čovekovom odnošenju prema svetu, u modernom svetu njeno mesto preuzima znanost. "Modernosti se prigovara da je čoveka stavila na mesto Boga" (str. 115). U društvenom smislu je odlikuje proces sekularizacije, jačanje države-nacije, ideologije, razuma, razvoj prava i slobodnog tržišta, znanosti i tehnologije. Nakon svetskih ratova dolazi do krize modernosti jer se pokazuje da nepravilna upotreba znanosti može da ima ogromne posledice po samo društvo. Dolazi do krize modernih ideja. Postmodernizam je termin koji je prvi upotrebio Arnold Toynbe 1960. Njega u osnovnim crtama odlikuje masovni konzumerizam i ratna ekonomija. Dolazi do krize ideologije, racionalnosti, ideja države-nacije, sekularizacije, marksizma... Tako na njihovo mesto stupa obnova tradicionalne religije, koja je naglašeno individualizovana. To znači da akcenat više nije na traženju sličnosti među religijama, nego upravo na negovanju njihove različitosti. Razlika se ne posmatra više kao nešto negativno, nego je prihvatanje različitosti zapravo postalo uslov mira $\mathrm{i}$ nenasilne komunikacije. Tako autor pokazuje važnost ovih teorija u savremenom svetu. Naglašava da je ovo ipak opšta slika i da postoje i druge teorije (npr. neki neomarksisti smatraju postmodernizam i individualizam prikrivenom ideologijom), ali to su neki presudni i ključni momenti koji odlikuju postmodernu.

Zanimljivo je to što autor nakon pokazivanja postmodernističke teorije $\mathrm{u}$ kojoj naglašava krizu sekularizma govori o sekularizaciji. To je zbog toga što autor pravi razliku između sekularizacije i sekularizma. Sekularizacija je prirodan proces koji "ima svoje plime i oseke" i njega odlikuje odvajanje religije od države u čijem temelju leži napredak pozitivnih znanosti. Autor nastoji da pokaže da proces sekularizacije ne mora nužno biti antireligijski, jer se i sama institucionalizovana religija služi nekim pravima do kojih se došlo u procesu sekularizacije. Za razliku od njega, sekularizam je ideologija i predstavlja na neki način "obogotvorenje" države i prava. Govoreći o sekularizaciji, autor ostaje otvoren za najrazličitija značenja koja ovaj termin nosi sa sobom. Veoma je korisno za čitaoce insistiranje na terminološkoj ispravnosti. Zbog toga 
autor naglašava da je proces sekularizacije nastao u Zadnjoj Evropi, ali da je njegova povest procesualnog karaktera na najrazličitijim regijama te da je validno jedino precizirati i govoriti konkretno o sekularizaciji jedino u odnosu na okolnosti. Osnovni zagovornici sekularizacije su Comte, Marx, Weber, Berger... Dobro je što se pokazuje i to da postoje i savremene teorije koje govore o postsekularizaciji, iako se sâm autor kritički odnosi prema ovim teorijama. On naglašava da sekularizacija ima i svoje pozitivne posledice, pre svega po pojedinca, jer mu ostavlja veću slobodu izbora u opredeljenju. "Biti sekularan ne znači biti nužno areligiozan" (str. 130).

Najobimnije i sadržinski najbogatije poglavlje jeste poglavlje o feminističkim teorijama. Feminističke teorije su se najviše razvijale u XX i XXI veku. Već po samoj strukturi i sadržaju ovog poglavlja vidi se važnost koju autor pridaje ovim teorijama. Autor otklanja mnjenja da je u feminističkim teorijama reč o mržnji suprotnog pola. Naime, ove teorije se bave pitanjem uloge žene u društvu, one same po sebi ne impliciraju nikakvu mržnju ni ideologiju. Neka najosnovnija podela bi bila na: 1. liberalne, koje stavljaju primat na individualne slobode i prava, i 2. radikalne, koje stavljaju primat na socijalnu zaštitu žene. Autor nam nudi niz perspektiva iz kojih možemo da govorimo u ulozi žene u društvu. Možemo da govorimo o prirodnom odnosu snaga između žene i muškarca, o ženinoj ulozi u društvu, o (ne)ugroženosti ženskih prava i (ne)izjednačenosti sa muškim, o pitanju kako je žena percipirana $\mathrm{u}$ različitim religijskim spisima, a kako u različitim religijskim praksama, o načinu na koji su žene postale deo religijske zajednice kao članovi osoblja, o obrazovanju žena kroz istoriju... Tako neke statistike pokazuju da su na primer u Adventističkoj crkvi žene brojnije, ima ih 70\% (str. 142), dok se u nekim državama muškarci pokazuju kao religiozniji, npr. Brazil, istraživanja iz 2010. god. (str. 145). Autor daje i niz različitih primera iz religijskih spisa i prakse, pa upoređuje različite hrišćanske religije i njihov odnos prema ženi sa islamom, judaizmom, budizmom, sikizmom, hinduizmom... Ovo poglavlje predstavlja jedno temeljno istraživanje. Autor pokazuje različite odnose prema ženi u svakoj od ovih religija i kako neke od njih u nekim aspektima veličaju važnost žene, dok druge nipodaštavaju njenu ulogu u društvu. Često je njihov odnos prema ženi slojevit i ambivalentan. Autor spominje i autore poput Webera i refleksije drugih sociologa o ovom pitanju. On pokazuje i određena statistička istraživanja kada i u kom procentu su žene postale zvanični članovi religijskih obreda (str. 215), kao i statistiku o odnosu visokoobrazovanih žena i muškaraca (str. 223.) On govori i o marksističkoj kritici kapitalizma koja akcenat stavlja na izrabljivanje i obrezvređivanje žene u kapitalističkom sistemu. U drugom delu teksta autor se bavi i pitanjem homo- 
seksualizma i rodnih studija. Tu takođe daje različite primere kako iz svetih spisa, tako i iz teorija i empirijskih istraživanja. Pokazuje otvorenost nekih crkvi za razumevanje gey zajednica, kao i sukob određenih praksi sa svetim spisima, ali i mogućnost da se isti spisi različito tumače. Što se tiče rodnih studija, feministkinje prave razliku između roda i pola. Naime, rod je sociološka kategorija kojom se žena društveno i kulturno određuje u određenom diskursu, dok pol predstavlja biološku kategoriju (str. 194.) Mnoštvo sadržaja i u ovom poglavlju može da zbuni čitaoca, ali različiti primeri koje autor navodi ukazuju na osnovnu autorovu nameru koja se provlači kroz celu knjigu, a to je zahtev za razumevanjem autentičnosti i različitosti.

Ovo su neke od osnovnih teorija koje autor razmatra. Najvažnije su još:

1. Teorija globalizacije. Nju autor razmatra paralelno sa postmodernizmom i kapitalističkim uređenjem sveta. On takođe otvara pitanje da li globalizacija utiče na očuvanje ili uništenje religijskog identiteta? Autor stavlja akcenat na pozitivne crte globalizacije: one je pre svega izvor verske i religijske tolerancije i proširenja sloboda (str. 229).

2. Ekološka teorija. Ona je povezana sa savremenim bioetičkim pitanjima i pitanjem očuvanja životne sredine. Autor naglašava pozitivnu funkciju religije, jer u većini religija čovek se posmatra kao vladar nad prirodom i on može da spreči do određene mere katastrofe samo ako se odrekne ličnog interesa i volje za moći. Tako religija može da pomogne u očuvanju životne sredine.

3. Fundamentalizam. Autor pravi razliku između fundamentalizma i konzervativizma i tradicionalizma. Fundamentalizam odlazi u krajnost i postaje ideologija, što znači da on svoje utemeljenje traži u nekim posebnim idejama i slepoj veri, i najčešće nije otvoren za razumevanje drugog. Akcenat je na izvornosti religijskih spisa i prakse. Autor je kritički nastrojen prema njemu i tvrdi da on često ne kaže ništa o samoj religioznosti (str. 259).

4. Humanizam. Teorije u okviru religije koje svoje učenje zasnivaju na renesansnim i racionalističkim idejama. Ključ je i akcenat na uvažavanju drugog. Pojam ljudskog dostojanstva i prava na sopstveno opredeljenje u ovim teorijama igra veliku ulogu. Autor afirmiše ove teorije i smatra da mogu biti veoma korisne za razvoj tolerancije i razumevanja drugog.

5. Teorije identiteta. Ove teorije čine veoma zanimljivo izlaganje. Samo pitanje identiteta je u savremenoj društvenoj nauci veoma otvoreno. Autor se bavi pre svega odnosom religijskog i nacionalnog identiteta i pokazuje da jedan ne implicira drugi nužno. Naime, identitet nije nešto fiksno. Onog momenta kada neko pokušava da apsolutizuje neki identitet, on postaje dogmatik i ideolog, a to autor svakako kritikuje jer takva ličnost ostaje zatvorena u sopstvenim uverenjima i opasna po druge. Vera se može razlikovati od naci- 
onalnog identiteta $\mathrm{i}$ tu autor daje niz primera u religiji, istoriji, savremenim dešavanjima kako u svetu tako i na Balkanu. I u ovom poglavlju on ističe važnost dijaloga u kreiranju sopstvenog identiteta i kako samo razumevajući drugog mi suštinski možemo donekle i sebe da odredimo.

6. Pravne teorije. Autor analizira pre svega odnos demokratije i religije. Pokazuje na istorijskim primerima kako je razvoj individualnih sloboda uticao na određene religijske zajednice i kako je sloboda mišljenja veoma važna i u religijskom samoopredeljenju.

7. Ostale teorije. Autor govori o nekoliko različitih teorija i analizira ih po istom principu na osnovu kog analizira i navedene teorije. Pokazuje poreklo određenih termina, istorijski proces nastanka određene teorije, njene ključne predstavnike, kako se ona odnosi prema određenim religijskim spisima $i$ praksi i njenu društvenu ulogu. Ono što ostaje ključno za autora jeste na koji način same teorije doprinose razvoju tolerancije i dijaloga.

Ne postoji samo jedna definicija onoga šta religija jeste. Međutim, Ivan Cvitković u svom delu Religija u zrcalu teorija pokazuje da to nije ništa loše niti negativno za samu religiju. Naprotiv. Različitost koja postoji prema zvaničnim, ali i nezvaničnim religijama i njihovim praksama je ono što je važno istaći. Različitost je ta koja svakoj pojedinačnoj religiji daje njeno sopstveno određenje, jer se pokazuje da svako sopstveni identitet stiče samo u odnosu prema drugom. Međutim, to ne znači da po svaku cenu treba insistirati na sopstvenoj različitosti. Autor pokazuje da postoji granica u ispoljavanju sopstvenog identiteta, a to je sloboda drugog da se ispolji. Pošto te granice nisu najjasnije u liberalnom kapitalističkom društvu, autor pokušava da ih ocrta kroz niz "važnih" i "manje važnih" teorija. Zbog toga je ova studija interesantna i sociologu, i psihologu, i pravniku, i verniku, i nekome ko se ne bavi isključivo ovim oblastima. Autor piše na jednostavan način i svako ko poseduje minimum opšteg obrazovanja može da prati ovu knjigu. Ipak, jednostavan jezik je privid, jer se ispod njega kriju složena filozofska pitanja. Na neka sâm autor odgovara, a neka ostavlja čitaocu da dovrši. Autor kroz svaku teoriju iscrpno izlaže njeno terminološko poreklo, zatim pokazuje njen nastanak i razvoj, način na koji su je reflektovali različiti autori, način na koji se tumači posredstvom religijskih spisa i prakse, i vrlo često pokazuje poređenje teorije sa savremenim svetskim dešavanjima. Važno je naglasiti da on u svakoj teoriji pokazuje njen pozitivan deo i razvoj, ali i zablude i opšta mnjenja koja vladaju vezana za tu teoriju. Ono što je ključno jeste što se pokazuje da ne može puka teorija odrediti religiju, ali to ne mogu učiniti ni empirijsko istraživanje ni statistika. Religija je fenomen koji "lebdi” između teorije i prakse, vere i dela. Tako je mišljenje autora pozicionirano negde iz- 
među modernosti i postmodernizma. On insistira na tome da se postave neki okviri i granice, ali da se istovremeno ostane otvoren i slobodan za razumevanje drugog. On pokazuje da nije loše očuvanje religioznog identiteta, ali da je važna i tolerancija. On skoro svako poglavlje završava pozivajući na mir i nenasilan način komunikacije. Ali autor nije naivan, on razmatra i ekonomske strukture i mogućnosti jednog ovakvog poziva. Da li je moguće misliti ovako, da li je moguće pomiriti savremenost i tradicionalizam, sveto i profano, autor ostavlja čitaocu da sâm zaključi. 